\title{
REFERENCES
}

1. Alifanov, V. V., and L. Ju. Popova. 2004. Znachenie semejstv v plemennoj rabote - The importance of families in breeding work. Zootehniya - Animal scince. 9:9-10 (in Russian).

2. Arsenov, L. T. 1974. Jeffektivnost' metodov plemennoj ocenki semejstv - Efficiency of methods of tribal evaluation of families. Zhivotnovodstvo - Livestock. 9:23-25 (in Russian).

3. Arsonov, L. T. 1979. Vykorystannia uzahalniuiuchoi kharakterystyky rozvytku rodyn za pokolinniamy dlia otsinky spadkovykh osoblyvostei koriv - Usage of the generalizing characteristic of the development of families by generations to assess the hereditary characteristics of cows. Molochno-miasne skotarstvo - Dairy and beef cattle breeding. 50:20-24 (in Ukrainian).

4. Vinnychuk, D. T. 1978. Dyferentsiatsiia i otsinka rodyn koriv - Differentiation and evaluation of the families of cows. Rozvedennya ta shtuchne osimeninnia velykoi rohatoi khudoby - Breeding and artificial insemination of cattle. 10:6-11 (in Ukrainian).

5. Vinnychuk, D. T. 1979. Osnovni pryntsypy rozvedennia za liniiamy v skotarstvi - Basic principles of breeding by lines in cattle. Molochno-miasne skotarstvo - Dairy and beef cattle. 49:38 (in Ukrainian).

6. Dzhus, P. P., O. V. Sydorenko, N. V. Chop, H. M. Bondaruk, and V. V. Tsuper-Korol. 2016. Henealohichna struktura matochnoho poholivia volynskoi miasnoi porody u plemzavodakh Turiiskoho raionu Volynskoi oblasti - Genealogical structure of the breeding stock of Volyn beef breed in the breeding stations of the Turiysky district of the Volyn region. Visnyk Sums'koho natsionalnoho ahrarnoho universytetu. Seriya «Tvarynnytstvo» - Bulletin of Sumy National Agrarian University, series of Animal Husbandry. 5(29):47-51 (in Ukrainian).

7. Voronenko, V. I., L. O. Omelchenko, N. M. Fursa, and R. V. Makarchuk. 2010. Henealohichna struktura tavriiskoho typu pivdennoi miasnoi porody velykoi rohatoi khudoby - Genealogical structure of the Taurian type of Southern beef cattle. Naukovyy visnyk «Askaniya-Nova» - Scintific Bulletin «Askania-Nova». 3:196-209 (in Ukrainian).

8. Dubin, A. M. 2000. Otsinka rodyn koriv u molochnomu skotarstvi - Evaluation of families of cows in dairy cattle breeding. Visnyk ahrarnoi nauky - Bulletin of Agrarian Scince. 6:48-50 (in Ukrainian).

9. Iliashenko, H. D. 2015. Formuvannia molochnoi produktyvnosti ta vidtvornoi zdatnosti koriv riznykh rodyn - Formation of dairy productivity and reproductive ability of cows of different families. Naukovyy visnyk «Askaniya-Nova»-Scintific Bulletin «Askania-Nova». 8:54-62 (in Ukrainian).

10. Plohinskij, N. A. 1969. Rukovodstvo po biometrii dlja zootehnikov-Biometrics guide for livestock specialists. Moskow, Kolos. 256 (in Russian).

11. Samusenko, A. I. 1971. Pleminna robota z liniiamy i rodynamy v skotarstvi - Tribal work with lines and families in cattle breeding. Pleminna sprava i biolohiia rozmnozhennia silskohospodarskykh tvaryn - Tribal affairs and biology of reproduction of farm animals. 1:7-9 (in Ukrainian).

УДК 636.2.034.06.082(477.51)

\section{ОЦІНКА ЖИВОЇ МАСИ ТЕЛИЦЬ РІЗНОГО ПОХОДЖЕННЯ В СТАДІ ТОВ «КРОК-УКРЗАЛІЗБУД»}

\section{O. B. PI3УH}

Інститут розведення і генетики тварин імені М.В.Зубия НААН (Чубинське, Украӥна) rizun.oleg@gmail.com

Дослідження проведені в стаді молочної худоби племінного заводу ТОВ «КРОК-УкрЗалізБуд» Прилуцького району Чернігівської області. Встановлено міжгрупову диферениіацію за живою масою телищь різного походження. Найвищу живу масу у віщі 18 місяџів мають телииі бугая Діснея 3014628800 голитинської породи, яка становить 413 кг. Жива маса всіх

Розведення і генетика тварин. 2018. Вип. 55

(C) O. B. PI3УH, 2018 
досліджених телищь у період від 6 до 18 місяиів відповідає стандарту породи. Коефіиієнти консолідованості живої маси телиць у досліджувані періоди є додатними і лиме у віщі 3 місяиів телиці бугаӥв Варнака 9537 і Доро 6917752 мають від’ємні значення. Консолідованість за живою масою телиць різних ліній має динаміку збільшення значень з $3(0,443)$ до 18 місяиів $(0,794)$.

Ключові слова: жива маса, телиці, консолідованість, бугаї, телиці

\section{EVALUATION OF LIVING MASS OF COTTONS OF DIFFERENT ORIGIN IN THE STAGE OF TOV "KROK-UKRZALIZBUD"}

\section{O. V. Rizun}

Institute of Animal Breeding and Genetics nd. a. M.V.Zubets of NAAS (Chubynske, Ukraine)

The research was carried out in the conditions of the breeding plant of KROK-UkrZalizBud Ltd, Pryluky District, Chernihiv region. Intergroup differentiation was established on the live weight of heifers of different origins. The largest mass at the age of 18 months have the calf of Disney's 3014628800 bull of Holstein, which is $413 \mathrm{~kg}$. The live weight of all tested heifers during the period from 6 to 18 months corresponds to the breed standard. The coefficients of consolidation of live weight of heifers during the studied periods are positive and only at the age of 3 months the heifers of the Burnak bullocks 9537 and Doro 6917752 have negative values. Consolidation for live weight of heifers of different lines has a dynamics of increase of values from $3(0,443)$ to 18 months $(0,794)$. Keywords: live weight, heifers, consolidation, age, bulls, heifers

\section{ОЦЕНКА ЖИВОЙ МАССЫ ТЕЛОК РАЗНОГО ПРОИСХОЖДЕНИЯ В СТАДЕ ТОВ «КРОК-УКРЗАЛИЗБУД»}

\section{О. В. Ризун}

Институт разведения и генетики животных имени М.В.Зубиа НААН (Чубинское, Украина)

Исследования проведены в стаде молочного скота племенного завода ООО «КРОКУкрЗализБуд» Прилуикого района Черниговской области. Установлено межгрупповую дифференцииацию по живой массе телок разного происхождения. Наибольшую массу в возрасте 18 месяцев имеют телки быка Диснея 3014628800 голштинской породы, которая составила 413 кг. Живая масса всех исследуемых телок в период с 6 до 18 месяиев соответствует стандарту породы. Коэффициенты консолидации живой массы телок в исследуемые периоды были положительными и только в возрасте 3 месяцев телки быков Варнака 9537 и Доро 6917752 имеют отрицательные значения. Консолидация по живой массе телок разных линий имеет динамику увеличения значений с $3(0,443)$ до 18 месяцев $(0,794)$.

Ключевые слова: живая масса, телки, консолидация, возраст, быки, телки

Вступ. Вирощування ремонтного молодняку є важливою складовою технології молочного скотарства, що безпосередньо чинить вплив на селекційний процес. Біологічні закономірності процесів росту і розвитку сільськогосподарських тварин потрібно вивчати задля можливості прогнозування майбутньої продуктивності. В молочному скотарстві формування тварин бажаного типу і прояв високої молочної продуктивності корів залежить від інтенсивності вирощування молодняку на всіх етапах онтогенетичного розвитку [7].

Встановлено [3], що телиці української чорно-рябої молочної породи, які мають високу інтенсивність росту, характеризуються гармонійним і пропорційним розвитком. Автор також зазначає, що з віком у дослідних тварин змінилися показники інтер'єру - збільшився вміст гемоглобіну, загального білку та зросли бактерицидна, лізоцимна та фагоцитарна активності.

Крім диференціації живої маси тварин у популяціях (стадах) існує висока мінливість за інтенсивністю росту в структурних підрозділах породи (лініях, родинах). Не менш важливими $\epsilon$ результати оцінки молодняку в групах напівсестер за батьком $[1,2,6]$.

Метою досліджень було провести оцінку телиць різного походження за живою масою в різні вікові періоди. У межах груп напівсестер за батьком визначити рівень консолідованості за живою масою. 
Матеріали та методи досліджень. Дослідження виконані в умовах племінного заводу ТОВ «КРОК-УкрЗалізБуд» Прилуцького району Чернігівської області. Об’єктом досліджень були дочки $(\mathrm{n}=1282)$ бугаїв української червоно-рябої молочної, голштинської та симентальської порід. Живу масу у віці $3,6,9,12,15$ та 18 міс. визначали за даними первинного зоотехнічного обліку. Консолідованість показника живої маси визначали за коефіцієнтами Ю. П. Полупана [5] за використання середньоквадратичного відхилення (К1) та коефіцієнта мінливості (К2) та середніх значень (Кс). Біометричну обробку результатів досліджень виконували за Н. А. Плохинским [4] за домогою програмного забезпечення Microsoft Excel. За діючими стандартами жива маса телиць голштинської та української червоно-рябої молочної породи у віці 6, 9, 12, 15 та 18 місяців становлить 175, 234, 288, 338 та 385 кг, тоді як у симентальської по-роди відповідно170, 229, 284, 334 та 380 кг.

Результати досліджень. Жива маса телиць як у межах порід, так і батьків має чітку диференціацію (табл. 1). За стандартом порід спостерігається тенденція збільшення живої маси телиць починаючи з 6 місяців. Так, відповідність стандарту живої маси телиць голштинської породи у віці 6 та 12 міс мають дочки одного бугая, у 12 міс. -9 бугаїв, 15 міс. -10 бугаїв та 18 міс. - 12 бугаїв. Жива маса телиць, які походять від симентальських бугаїв, у більшості випадків відповідає стандарту.

Різниця між лімітними значеннями живої маси телиць від бугаїв голштинської породи червоної масті у віці 3, 6, 9, 12, 15 та 18 місяців становить, відповідно, 12, 39, 58, 66, 80 та 70 кг. Тоді, як у телиць, які походять від симентальських бугаїв, відповідні значення більш вирівняні і найбільша різниця спостерігається у віці 12 місяців (39 кг).

Найвищу живу масу дочок серед бугаїв голштинської породи червоної масті до 9 місяців мають Туріно 660563141, у 18 місяців - Херо 22838175 і Доро 6917752. Понад 400 кг у віці 18 місяців мають телиці шести бугаїв голштинської породи. У симентальських бугаїв слід відмітити дочок Кремнія 691 і Роллера 220593945, які у 18 місяців переважають дочок Варнака 9537 і Дранка 1551 за живою масою на 20 кг.

За коефіцієнтами консолідованості живої маси дочок бугаїв відмічено високі і додатні значення, які поступово підвищуються з 6 до 18 місяців (табл. 2). У віці 3 місяців від'ємні значення коефіцієнтів консолідації мають дочки бугаїв Доро 6917752 та Варнака 9537. Мінімальні значення консолідованості за живою масою дочок серед бугаїв голштинської породи червоної масті відмічено у Імпорта 1048, а максимальні у Туріно 660563141. Серед симентальських бугаїв мінімальні значення мають дочки бугая Варнака 9537 з середнім значенням 0,359, а максимальні дочки Кремнія 691 (0,638). Дочки бугая Діснея 3014628800 голштинської породи є консолідованими, оскільки значення є додатніми і коливаються в межах $0,520 \ldots 0,774$.

Міжгрупова диференціація телиць різних ліній за живою масою незначна і становить у віці 3, 6, 9, 12, 15 та 18 місяців - 3, 2, 11, 13, 4 та 12 кг. 33 до 12 місяців найвища жива маса телиць спостерігається у дочок лінії Кавалера 1620273, тоді як з 15 до 18 місяців - у телиць лінії Елевейшна 1491007 (табл. 3).

Встановлено, що з трьох місяців коефіцієнти консолідованості за живою масою поступово підвищуються (табл. 4). Відмічено, що значення коефіцієнту консолідованості за живою масою телиць різних ліній поступово збільшується з віком, а їх динаміка зростає від трьох $(K=0,443)$ до 18 місяців $(K=0,794)$. Різниця між середніми значеннями коефіцієнтів 3 трьох до 18 місяців у телиць лінії Елевейшна 1491007 становить 0,322, а Кавалера 1620273 i Чіфа 1427381 - 0,365.

Висновки. Встановлено міжгрупову диференціацію за живою масою телиць різного походження. Дочки бугаїв голштинської породи червоної масті Туріно 660563141, Херо 22838175, Доро 6917752 і симентальських Кремнія 691 і Роллера 220593945 мають найвищі значення живої маси телиць у досліджувані періоди. Суттєвої переваги у живій масі телиць ліній Елевейшна 1491007, Кавалера 1620273 та Чіфа 1427381 не встановлено. За коефіцієнтами консолідованості живої маси телиць різних ліній у різні вікові періоди отримані високі додатні значення в межах 0,360 ... 0,853. 


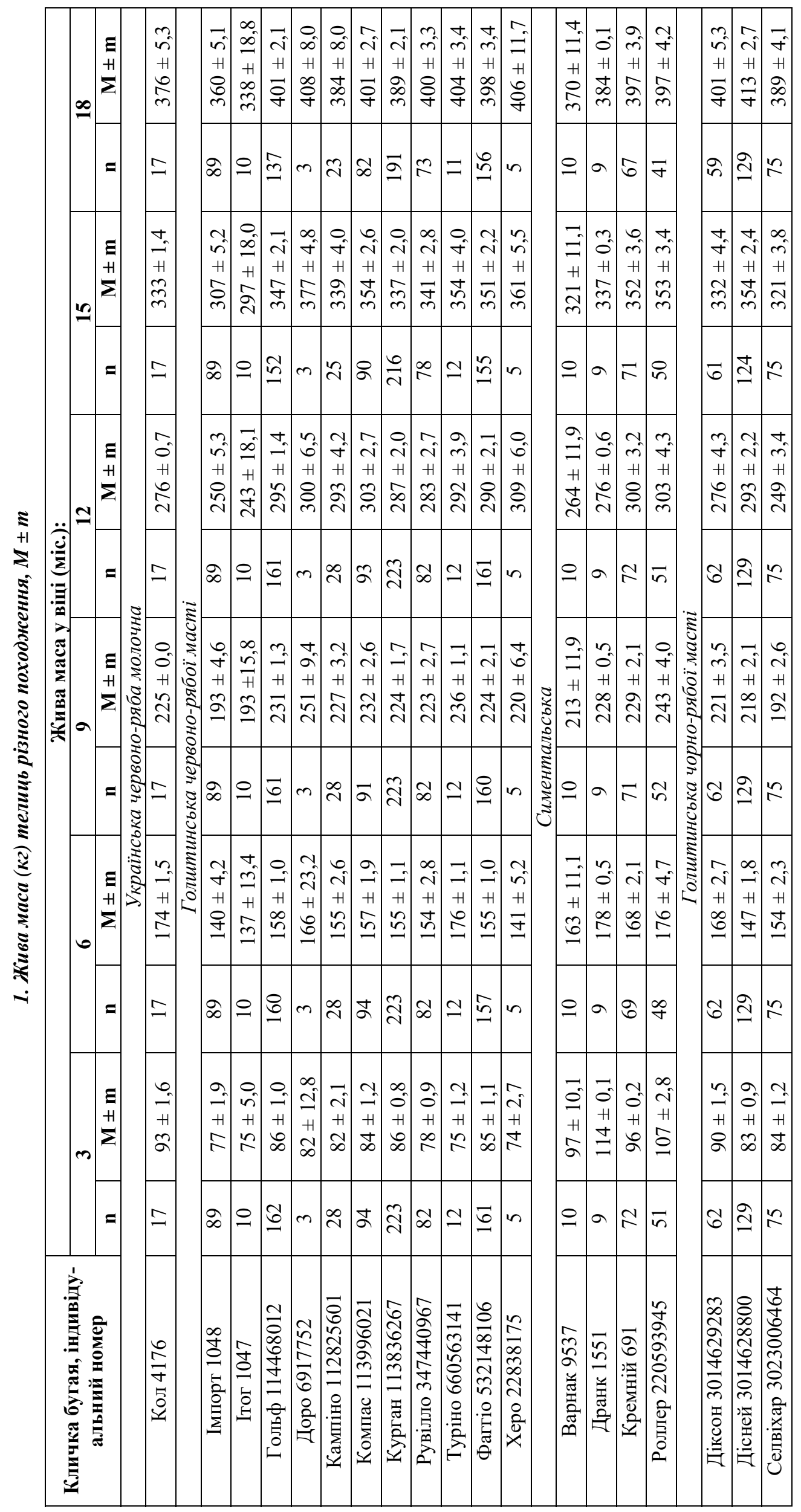




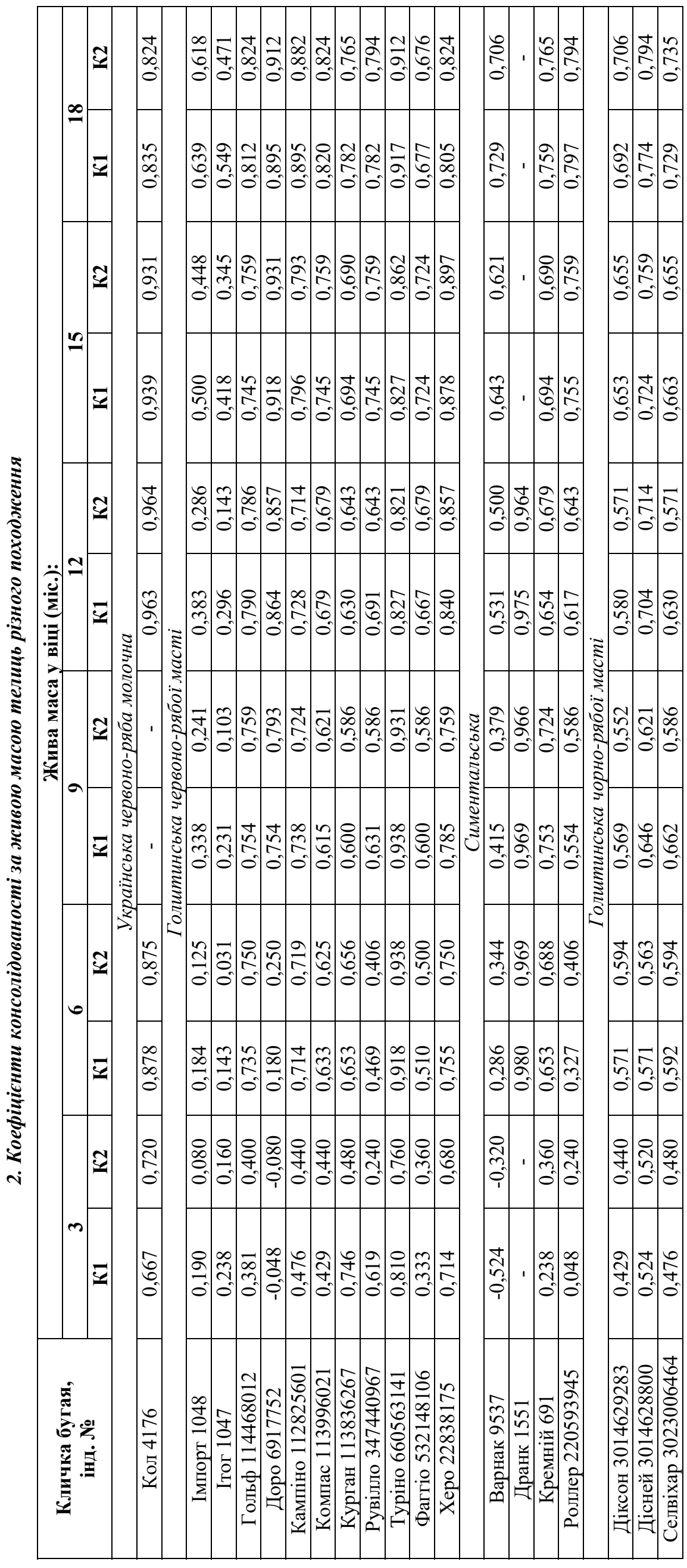



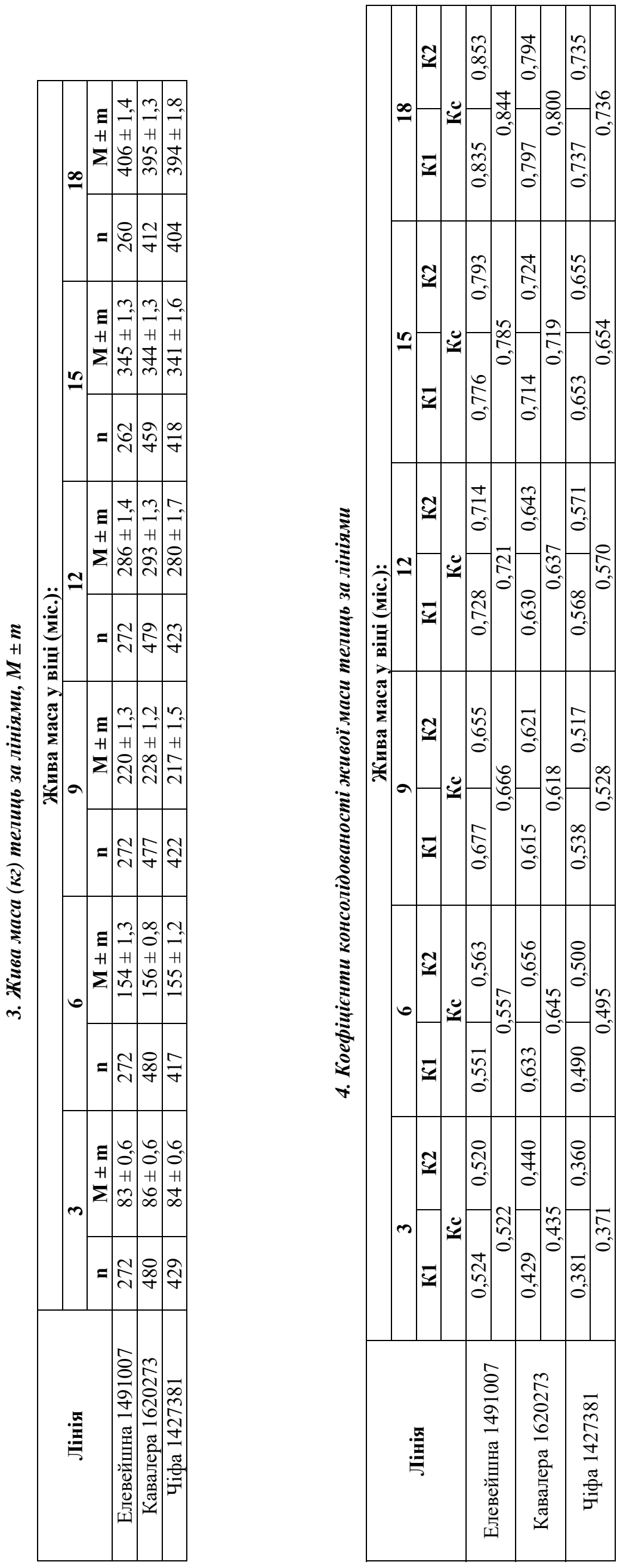


\section{БІБЛІОГРАФІЯ}

1. Бабич, Е. А. Влияние генотипа на рост и развитие телок внутрипородного типа каратомар / Е. А. Бабич, Л. Ю. Овчинникова // Зоотехния. - 2017. - № 6. - С. 18-21.

2. Димчук, А. В. Ріст живої маси телиць подільського заводського типу української чорнорябої молочної породи / А. В. Димчук, О. І. Любинський // Розведення і генетика тварин. 2015. - Вип. 49. - С. 85-89.

3. Кузів, М. І. Ріст і розвиток та біологічні особливості телиць української чорно-рябої молочної породи в динаміці до річного віку / М. І. Кузів // Науковий вісник «Асканія-Нова». 2012. - Вип. 5, ч. II. - С. 88-94.

4. Плохинский, Н. А. Руководство по биометрии для зоотехников / Н. А. Плохинский. - М : Колос, 1969. - $256 \mathrm{c}$.

5. Полупан, Ю. Методи визначення ступеня фенотипової консолідації селекційних груп тварин / Ю. Полупан // Вісник аграрної науки. - 2002. - № 1. - С. 48-52.

6. Понько, Л. П. Динаміка продуктивності телиць основних ліній української чорно-рябої молочної породи в умовах Поділля України / Л. П. Понько // Науковий вісник ЛНУВМБТ ім. С. 3. Гжицького. - 2011. - Т. 13, № 4 (50), ч. 3. - С. 279-282.

7. Светова, Ю. А. Рост и развитие телок голштинской породы различного екогенеза/ Ю. А. Светова, Т. А. Гусева // Зоотехния. - 2014. - № 10. - С. 17-18.

\section{REFERENCES}

1. Babich, E. A., and L. Ju. Ovchinnikova 2017. Vlijanie genotipa na rost i razvitie telok vnutriporodnogo tipa karatomar - The influence of the genotype on the growth and development of heifers of the intra-breed type of caratomar. Zootehnija-Animal science. 6:18-21 (in Russian).

2. Dymchuk, A. V., and O. I. Lyubyns'kyy. 2015. Rist zhyvoyi masy telyts' podil's'koho zavods'koho typu ukrayins'koyi chorno-ryaboyi molochnoyi porody - Growth of live weight of heifers of Podilsky regional type of Ukrainian Black-and-White Dairy cattle. Rozvedennya i henetyka tvaryn - Animal breeding and genetics. 49:85-89 (in Ukrainian).

3. Kuziv, M. I. 2012. Rist i rozvytok ta biolohichni osoblyvosti telyts' ukrayins'koyi chorno-ryaboyi molochnoyi porody v dynamitsi do richnoho viku - Growth and development and biological peculiarities of heifers of Ukrainian Black-and-White Dairy cattle in the dynamics of the old age. Naukovyy visnyk «Askaniya-Nova»-Scientific Bulletin "Askania-Nova". 5:88-94 (in Ukrainian).

4. Plokhinskiy, N. A. 1969. Rukovodstvo po biometrii dlya zootekhnikov - Biometrics guide for livestock specialists. Moskov, Kolos, 256 (in Russian).

5. Polupan, Yu. P. 2004. Zonal'ni zavods'ki typy ukrayins'koyi chervonoyi molochnoyi porody Zonal factory types of Ukrainian Red Dairy Breed. Tvarynnytstvo Ukrayiny - Animal breeding of Ukraine. 5:11-16 (in Ukrainian).

6. Pon'ko, L. P. 2011. Dynamika produktyvnosti telyts' osnovnykh liniy ukrayins'koyi chorno-ryaboyi molochnoyi porody v umovakh Podillya Ukrayiny - Dynamics of productivity of heifers of the main lines of Ukrainian Black-and-White Dairy cattle breeding under conditions of Podillya of Ukraine. Naukovyy visnyk LNUVMBT im. S. Z. Gzhyts'koho - Scientific Bulletin of LNUWMBT named after. S. Z. Gzhytsky. 3:279-282 (in Ukrainian).

7. Svetova, Ju. A., and T. A. Guseva. 2014. Rost i razvitie telok golshtinskoj porody razlichnogo ekogeneza - Growth and development of heifers of the Holsteinian breed of various eco-genesis. Zootehnija - Animal science.10:17-18 (in Russian). 